\title{
The Author Reply: Mitochondrial Ophthalmoplegia Is Not Only due to mtDNA Deletions
}

\author{
Young-Mock Lee \\ Department of Pediatrics, Gangnam Severance Hospital, Severance Children's Hospital, Yonsei University College of Medicine, Seoul, Korea.
}

We have read the comments on our study by Dr. Finsterer. We thank Dr. Finsterer for these important points and agree that there is a shortcoming in our current study.

It is well-known that mitochondrial diseases are a heterogeneous group of disorders, and they often show important differences in phenotype and severity. Generally, classification of a syndrome or disease relies on accurate clinical, biochemical, and genetic information and may be based on either genotype or phenotype. Drawing a clear line to classify mitochondrial diseases, however, can be difficult since there is significant overlap among them: ${ }^{1,2}$ The diagnostic criteria for Kearns Sayre syndrome have not yet been completely established, as is the case with other mitochondrial diseases. Meanwhile, Leigh disease, a representative mitochondrial disease, has subclasses, such as Leigh syndrome and Leigh-like disease. ${ }^{3}$

Our study was retrospective in nature, and it has some limitations. Because of the rarity of the study disease, the size of our study population was small, which could have given the impression of a study not sufficient enough to make generalized interpretations. However, I would like to stress to readers that mitochondrial diseases are very rare, such that data on these diseases are limited to a degree that makes the research thereof extremely difficult. ${ }^{4,5}$ Despite the lack of copious amounts of data, however, the fact that mitochondrial disease is heterogenous calls for the establishment of better classification and further studies to generalize its homogeneous aspects.

\footnotetext{
Received: January 2, 2019

Corresponding author: Young-Mock Lee, MD, PhD, Department of Pediatrics, Yonsei University College of Medicine, 211 Eonju-ro, Gangnam-gu, Seoul 06273, Korea.

Tel: 82-2-2019-3350, Fax: 82-2-2019-4881, E-mail: ymleemd@yuhs.ac

-The author has no potential conflicts of interest to disclose.

(C) Copyright: Yonsei University College of Medicine 2019

This is an Open Access article distributed under the terms of the Creative Commons Attribution Non-Commercial License (https://creativecommons.org/licenses/ by-nc/4.0) which permits unrestricted non-commercial use, distribution, and reproduction in any medium, provided the original work is properly cited.
}

Confirmative diagnosis of pediatric patients with mitochondrial diseases by genetic diagnostic testing is very important. Over the past decade, technologies have continuously evolved and have enabled the use of sequencing as a clinical tool with better accessibility. However, in actual clinical settings, it is not easy to consistently apply confirmatory genetic diagnostic testing to all patients. Therefore, we tried to come up with common diagnostic criteria that could be applied objectively to all pediatric patients, and we wanted to emphasize the importance of gene study when evaluating phenotypes of a certain syndrome, such as Kearns Sayre syndrome. ${ }^{6}$ Nonetheless, further studies on phenotypes and genotypes, including mtDNA and nuclear DNA, of a variety of different syndromes should be attempted in the future.

We do agree and understand Dr. Finsterer's view on these points, and there is no question that a properly controlled, multicenter study or analysis with larger sample would be ideal. Again, we sincerely appreciate Dr. Finsterer's inspiring and insightful comments on this study.

\section{ORCID iD}

Young-Mock Lee https://orcid.org/0000-0002-5838-249X

\section{REFERENCES}

1. Kisler JE, Whittaker RG, McFarland R. Mitochondrial diseases in childhood: a clinical approach to investigation and management. Dev Med Child Neurol 2010;52:422-33.

2. Horvath R, Hudson G, Ferrari G, Fütterer N, Ahola S, Lamantea E, et al. Phenotypic spectrum associated with mutations of the mitochondrial polymerase gamma gene. Brain 2006;129(Pt 7):1674-84.

3. Finsterer J. Leigh and Leigh-like syndrome in children and adults. Pediatr Neurol 2008;39:223-35.

4. Baek MS, Kim SH, Lee YM. The usefulness of muscle biopsy in initial diagnostic evaluation of mitochondrial encephalomyopathy, lactic acidosis, and stroke-like episodes. Yonsei Med J 2019;60:98-105 
5. Eom S, Lee HN, Lee S, Kang HC, Lee JS, Kim HD, et al. Cause of death in children with mitochondrial diseases. Pediatr Neurol 2017;66:82-8.
6. López-Gallardo E, López-Pérez MJ, Montoya J, Ruiz-Pesini E. $\mathrm{CPEO}$ and KSS differ in the percentage and location of the $\mathrm{mtD}$ NA deletion. Mitochondrion 2009;9:314-7. 